\title{
Opinions of Teacher Candidates on the Usage of Mobile Applications in the Multimedia Development Processes
}

\author{
https://doi.org/10.3991/ijim.v12i2.7679 \\ Fezile Ozdamli( $\left.{ }^{\varpi}\right)$, Erinc Ercag \\ Near East University, Nicosia, Cyprus \\ fezile.ozdamli@neu.edu.tr
}

\begin{abstract}
In order for mobile applications to be employed successfully in education, the opinions of teachers on the use of these applications must be identified and improved. For this reason, the purpose of this study is to identify the opinions of teacher candidates, who are the teachers of the future, on the usage of mobile applications in the process of multimedia project development. This study, which was conducted with the purpose of identifying the opinions of teacher candidates on the usage of mobile applications in education as a means of communication, employed a qualitative method. The results indicate that using mobile applications in the multimedia project development process attracted the attention of students and ensured effective communication.
\end{abstract}

Keywords - mobile learning, multimedia development, teacher candidates

\section{Introduction}

It is observed that wireless connections, GPRS connections, Bluetooth and infrared connection facilities are increasingly employed so that mobile devices can connect online individually or in combination with each other. Additionally, there has been significant development in mobile device technologies such as recording, transferring and transforming to the various formats of mobile devices. These developments in mobile technologies have ensured that these technologies can be used for educative purposes. Mobile devices with wireless networks have significant potential for formal and informal education. Several learning activities can be performed with mobile devices. Mobile learning can be used with the purpose of supporting conventional learning [1] as well as for distance learning [2,3,4].

Analysis of the literature about learning and teaching reveals that in-class activities are insufficient and extra-class activities should be included so that an effective environment can be created $[5,6,7]$. However, many teachers state that insufficient effort is being paid to the extra-class activities of students. Alessi and Trollip [8] claim that this is due to a lack of motivation. With mobile technologies, the motivations of students can be increased without the necessity to sit and study in front of a computer and extra-class activities can be organized.

Education not only serves to prepare students for life; it is life in itself. The education of an individual is realized within his/her culture and in a mutual communication 
process with other individuals in his/her society. The basic elements of the communication process include such concepts as source, message, channel, receiver and feedback. However, it is observed that this kind of communication is unidirectional. It is acknowledged that bi-directional communication is needed so that students can achieve their goals. In order to ensure student-centered education, the communication process should be based on constructivist learning theories. In terms of the constructivist learning environment, the interaction established with the student is more important than conveying the desired message.

Moore [9] mentions three types of interaction, namely, student-student, studentteacher and student-content. Anderson [10] discusses the process between studentteacher, student-student and student-material based on the constructivist learning approach. Çuhadar and Kıyıcı [11] stated that in the learning process of distant education based on constructivist learning, interactions occur between student-content, student-student, student-teacher and student-media. The environment suitable for students to use their knowledge and display their unique viewpoints can be realized by creating a rich interaction environment between students [11]. Different from the foregoing, Gülbahar [12] added the interaction between teachers as another type of interaction. According to Oloruntoba [13], mobile learning provides more flexible opportunities to students and teachers for interaction. Teachers must create interaction with other teachers in the process and share knowledge and experiences among themselves. Teachers can share different experiences with each other in technical matters and offer different suggestions. Experiencing different viewpoints will always be beneficial, which will increase the success of applications. In all the interaction types given above, it is noticeable that the student is at the center.

Students are the basic components of the system in mobile learning applications, and assume more responsibility compared to conventional learning environments. In mobile learning applications where mobile devices are used, students can interact with their teachers, peers and course contents whenever and wherever they want. With mobile learning applications, students can continue their communication by participating in extra-class activities through media such as blogs, chats, forums and wikis. If constructivist learning is taken as the basis, the student has to interpret his/her own knowledge and actively participate in the learning process. In learning processes performed using mobile devices, students have the opportunity to receive instant feedback from the activities and learn from their teachers and other peers. Learning is realized more rapidly by students who receive instant feedback.

According to the explanations given above, the basic elements for mobile learning applications are student at the center as well as the teacher, environment and content. According to new approaches in education, the student is at the center of learningteaching activities. All other elements serve the student. Before planning and activating m-learning applications, the focus should be on the student. The student assumes an active role from the determination of targets to the evaluation stage. In mobile learning, the student is an individual who is responsible for his/her own learning in line with his/her own needs and area of interest in accordance to his/her own learning speed. Furthermore, the student is able to explore and use their own learning styles, can reach knowledge at the moment it is required, construct the information he/she 
learns and produce and share new knowledge/product, and work in cooperation with his/her peers who are distant when necessary. Suitable media must be organized so that the experiences of students in mobile learning applications move in a positive direction. In order to obtain successful results, teachers must take the learning styles of students into consideration. For example, some students can learn better in environments where audio, video and visuals are included. Additionally, they are required to actively participate in classes, participate in synchronous or asynchronous activities in accordance with the rules and within the determined time period, possess mobile technologies and use them in an effective way in order to complete their assignments. Gülbahar [12] states that regardless of whether classes are delivered in conventional or electronic media, this does not affect the student attendance and active participation in classes and that they have to meet these requirements in both styles of lecturing. Howell and Lee [14] state that with mobile learning, students are not passive but are active participants, not only producing knowledge but sharing the knowledge they produce. Furthermore, they do not participate as experts and learn individually, but learn in cooperation.

Current developments in storing knowledge and using technology have increased the accessible sources of information for students in terms of both volume and genre. This, in turn, has created a new dimension which is dissimilar to the conventional teacher roles in terms of seeking and using knowledge [15]. The role of the teacher is changing within the scope of mobile learning applications. The guiding, directing and collaborative-learning characteristics of teachers are coming to the forefront instead of merely the transferal of knowledge. The teacher who acts as a guide helps student in their knowledge construction processes.

According to researchers [16], the purpose of teachers in using information and communication technologies is not to ensure that the most innovative technologies are used, but that they use technologies that are suitable for their needs and purposes. In regard to the use of technology, the first step must be to determine whether the attitude of teachers towards technology is positive or not. The next step must be to ascertain the technological competences of teachers and the development of the program in this direction. Employment of technology by teachers consists of four stages $[17 ; 16]$. These stages are the adherence stage, comprehension stage, influencing stage and renewal stage.

The first stage, the adherence stage, is where teachers experience application problems in their usage of technology in teaching-learning processes in their own field as well as adaptation problems. In the comprehension stage, teachers develop coping strategies for the problems they experienced in technology usage and try to adapt to this new situation. In the influencing stage, they share their experiences with their colleagues regarding technology usage in the teaching-learning process. Thus, they create an effective and efficient learning environment and influence their students and colleagues with their experiences. In the final stage, which is the renewal stage, they introduce new innovative technology in their learning-teaching activities and renew themselves so that they can proceed towards specialization [16;17]. Faculties who train teachers are responsible for promoting Technological Pedagogical Content Knowledge (TPCK) [18]. Teacher educators must be technology literate so that they 
Paper-Opinions of Teacher Candidates on the Usage of Mobile Applications in the Multimed...

can combine mobile technologies and social media tools with course content. As mentioned above, in order for mobile applications to be employed successfully in education, the opinions of teachers regarding the use of these applications must be identified and improved. For this reason the purpose of this study is to identify the opinions of teacher candidates, who are teachers of the future, on the usage of mobile applications in the process of multimedia project development.

\section{$2 \quad$ Method}

This study, which was conducted with the purpose of identifying the opinions of teacher candidates on the usage of mobile applications in education as a means of communication, employed the qualitative method.

\subsection{Procedure}

The working group of the study consisted of 23 teacher candidates who were taking the Multimedia Development Course in the Department of Computer and Teaching Technology Education. Multimedia development course videos were prepared by the teacher and questions were added inside the Vizia application, which were uploaded to Moodle media. Each student group that conducted projects within cooperative learning groups identified the mobile application that would be used with the purpose of ensuring communication with teachers and among themselves. At the beginning of the semester, students installed Moodle and other mobile applications on their phones. Students preferred Viber, WhatsApp and Messenger applications for communication purposes. Researcher students were asked to use Tellagami, Padlet and Movie Edit Touch Applications while developing multimedia. Students created educative videos using the Tellagami application on their phones and uploaded them on their Padlets. The teacher candidates viewed course videos on Moodle media while developing the multimedia development for which they were responsible during the 14 weeks and communicated with each other and their teachers whenever they wanted. Figure 1 gives examples of the media used.

In the learning process of the teacher candidates, a semi-structured interview form was used with the purpose of determining their opinions on the use of mobile applications for material development and communication purposes. Opinions of faculty staff who delivered the Multimedia development course and education technologists were obtained and minor changes were made to the prepared form according to their suggestions. At the end of the semester, the researcher interviewed all the teacher candidates and recorded these interviews on his phone after permission had been obtained. Each interview lasted for approximately 15 minutes. The data obtained were subjected to content analysis individually by the researchers. The harmony between the two encoders was calculated as 88 percent. The controversial parts were reviewed and corrections were made. One expert who did not participate in the study performed a double-check in order to ensure the reliability and quality of the data. The categories that were formed after coding were tabulated as frequencies. Additionally, the ob- 
tained qualitative data were supported with direct citations from the opinions of the teacher candidates. In these citations, the names of the teacher candidates were kept confidential and were marked as Learner.
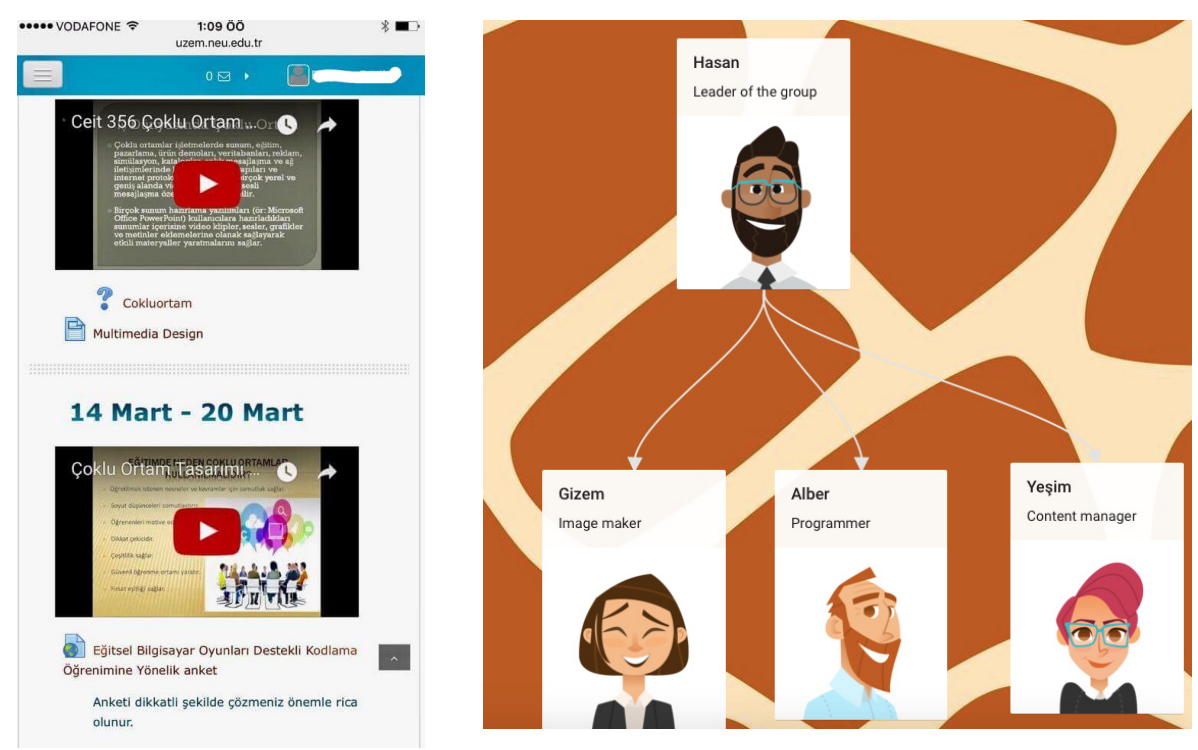

Fig. 1. Mobile Moodle and Padlet Screenshoot

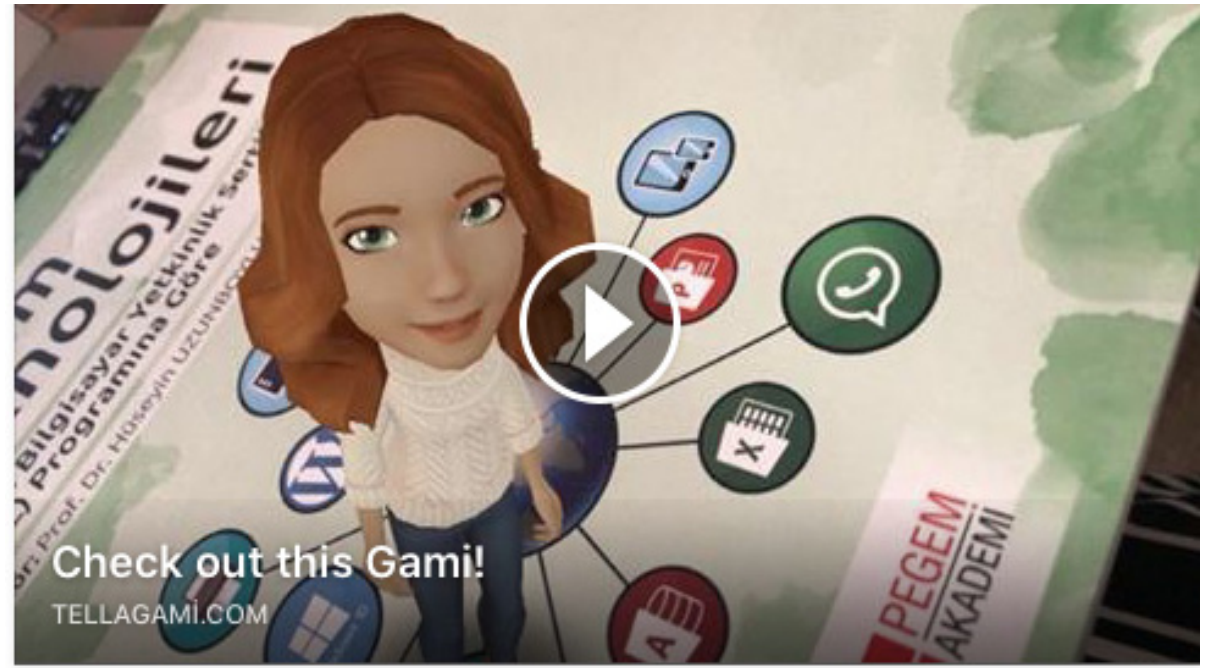

Fig. 2. Course video prepared with Tellagami 


\section{Results}

The findings obtained from the answers given to the questions asked to the teacher candidates with the purpose of determining their opinions on using mobile applications with the purpose of multimedia development and communication are provided below.

\subsection{Online tools used for supporting learning activities}

With the purpose of determining the mobile applications used for educative purposes, the teacher candidates were asked the question "which applications have you used so far for education purposes?" According to the obtained findings, it was found that "E-mail", "Facebook", "Edmodo", "Moodle" and "Kahoot" were used as supportive tools for the education of teacher candidates.

Table 1. Tools used to support learning activities

\begin{tabular}{|c|c|}
\hline & f \\
\hline E-mail & 21 \\
Facebook & 11 \\
Moodle & 9 \\
Edmodo & 2 \\
Kahoot & 2 \\
\hline
\end{tabular}

As can be seen in the table above, most of the students who participated in the study have an e-mail application on their phones and use it constantly. Additionally, when the most widely used applications are considered, Facebook was the most frequently used social web site. Moodle, Edmodo and Kahoot are also other applications that they used. Some of the answers given by students are given below:

Learner3: "In most of our courses, we send our homework and projects to our teachers through e-mail. In some courses, using Moodle media, we can receive the documents that our teacher shares and upload our projects."

Learner7: "The application we use most frequently is e-mail. For each course, we send our projects or homework through e-mail or Moodle."

Learner21: "In our group work, we formed a Facebook group and share information with our friends. In addition, we send our teacher necessary documents through Moodle or e-mail."

Learner9: "We are using e-mail and Moodle all the time, but last semester, we used the Edmodo and Kahoot applications in one course, both of which made positive contributions."

\subsection{Differences made by mobile applications in learning activities}

In the study, the question "What kind of impact did the mobile applications you used in the multimedia development course have on the learning process?" was asked with the purpose of determining the impact created by using mobile applications in 
the learning process. Such themes as "interesting”, "effective communication", "preparation of projects", "motivating" and "collaboration" were obtained in regard to the learning process of the used mobile applications. Frequencies related to these themes are given in the table below. When the differences made by mobile applications in learning activities are examined, it can be seen that the majority of students stated that using mobile technologies in learning activities created a positive impact.

Table 2. Differences in learning activities

\begin{tabular}{|c|c|}
\hline & f \\
\hline Interesting & 21 \\
Effective communication & 18 \\
Preparation of projects & 15 \\
Motivating & 15 \\
Collaboration & 13 \\
\hline
\end{tabular}

Students who participated in the study showed significant interest in Padlet and instant messaging applications in particular.

Learner19: "Especially the Padlet application was interesting; it provided convenience so that we could work in cooperation. We dragged the multimedia elements that we developed to the Padlet media and received feedback and corrections from our teammates."

Learner16: "The course became more enjoyable with the applications used"

Additionally, students stated that usage of instant messaging applications allowed for effective communication with their teachers and teammates.

Learner12: "We preferred using Viber for communication purposes with our teachers and teammates so that we could create an effective communication environment. We do not have to check our e-mails or call on the phone in order to obtain information from each other. I think that this kind of application must be used in all courses. Moreover, we began to follow the same path in our project groups in other courses. We are finding and trying free-of-charge applications such as Padlet. Before, we were progressing with our projects through our Facebook groups, but you cannot deny that there are distracting elements."

With the purpose of determining the mobile applications used for educative purposes, the teacher candidates were asked the question "what applications have you used so far for education purposes?" According to the obtained findings, it was found that "E-mail", "Facebook", "Edmodo", "Moodle" and "Kahoot" were used as supportive tools for the education of teacher candidates.

\subsection{References The most popular features of mobile applications}

One of the aims of this study was to determine which features were most widely used in mobile applications that were employed for communication purposes. Within this scope, teacher candidates were asked the question "what were the most widely used features of the applications you chose while developing your multimedia projects?" 
Table 3. Features of mobile application

\begin{tabular}{|c|c|}
\hline & f \\
\hline Messaging & 20 \\
Course note sharing & 16 \\
Sharing instructional videos & 7 \\
Online course material sharing & 4 \\
\hline
\end{tabular}

When the most widely used features of the Viber, WhatsApp and Messenger applications that the teacher candidates determined themselves and used with the project groups and the trainer were examined, it was revealed that communication was conducted in an audio-visual manner and that they tried to solve problems though voice calling and messaging features. The opinions of teacher candidates on this subject are provided below:

Learner 14: "I share the ideas that come to my mind with my group friends through instant messages."

Learner 16: "I accessed missing lecture notes through Moodle and the instant messaging application"

Learner 7: "I use them mostly for sharing files; when we have homework we can send the file to our teacher and receive feedback rapidly"

When the findings obtained from the opinions of teacher candidates are examined, it can be observed that the most widely used features were messaging and lecture note sharing. The teacher candidates stated that they used the screen sharing application with their friends for information sharing for the topics with which they had difficulty in the multimedia development course and received help from their peers and the lecturer.

\subsection{Missing/negative aspects of the used mobile applications}

In the multimedia project development course, the teachers who used mobile applications were asked the question "what are the missing/negative aspects of the mobile applications you use?" with the purpose of determining their negative opinions on the applications.

Table 4. Missing / adverse aspects of mobile applications

\begin{tabular}{|c|c|}
\hline & f \\
\hline Spend Internet quota & 4 \\
Inadequate screen size & 3 \\
\hline Message others & 1 \\
\hline
\end{tabular}

As can be seen in the table above, one of the negative aspects of the application that the teacher candidates mentioned was that it finished their Internet quotas prematurely. Three teacher candidates stated that the screen size was not sufficient, whereas one teacher candidate complained that he was disturbed by constant incoming messages. 
Paper-Opinions of Teacher Candidates on the Usage of Mobile Applications in the Multimed...

Learner13: "We have to work on videos while developing multimedia projects. Our Internet quota decreases while uploading and downloading videos we developed online."

Learner21: "I think that using a mobile device is not healthy as the screen is very small and I cannot work comfortably."

Learner19: "As my teammates are working at different hours of the day, messages are coming from the group constantly; although it can be viewed as a positive aspect, I begin to think about the project when I am doing other things"

\section{Discussion and Conclusion}

In the age of informatics when the usage ratio of mobile device and applications is increasing on a daily basis, multimedia projects are gaining importance. Additionally, it is inevitable that multimedia projects are being developed using these applications in education. The aim of this study was to determine the opinions of teacher candidates on the usage of mobile applications in multimedia project development stages and for 14 weeks, teachers and teacher candidates used mobile applications with the purpose of communicating and developing multimedia. According to the results obtained in the study, it was concluded that teacher candidates predominantly used email and Facebook applications for communication purposes prior to the implementation of this study. Furthermore, Edmodo and Moodle mobile applications were among those that they had used in gamification activities before and it was found that they had positive attitudes towards these applications.

Another finding is that the use of mobile applications in the multimedia project development process attracted the interest of students and ensured effective communication. Parallel to these findings, Imlavi, Gregg and Karimi [19] stated that creating online groups with these applications provided favorable opportunities for continuing communication and education through these groups. It was reported that by using mobile applications in the multimedia project development process, project preparation became easier and motivation and communication opportunities were provided. In a similar study, Can [20] stated that using mobile applications as a support for learning activities provided space for active collaboration.

According to the obtained results, the most widely used features by teacher candidates in instant messaging were voice calls and messaging. According to the results obtained from the teacher opinions, the free-of-charge voice call, messaging and file sharing features of instant messaging applications ensured that they communicated instantly and were able to contact their teachers or teammates whenever they experienced problems. In other studies in which mobile learning applications were realized, it was concluded that communication between students was easier $[21 ; 22 ; 23 ; 24 ; 25]$. The problems faced by teacher candidates when using mobile applications were listed as the requirement of preparing and uploading videos online as well as viewing and downloading them, which exhausted their Internet quotas and generated additional charges. Furthermore, as mentioned by a few students, another problem was that the screen size was not sufficient for working on the application. In order to prevent these 
Paper-Opinions of Teacher Candidates on the Usage of Mobile Applications in the Multimed...

problems, a Wi-Fi connection must be provided not only in the classrooms, but throughout the entire campus.

In conclusion, this study, which was conducted with the purpose of examining the usage of mobile applications in the multimedia project development process, teacher candidates generally provided positive opinions on the usage of applications and made several recommendations. However, as in every study, this study has its limitations. The most important limitation of the study is that it used a qualitative method. This qualitative study, which was conducted with the purpose of collecting in-depth information, can be supported with quantitative methods in the future. Additionally, project development applications for multimedia project development other than mobile applications can be used and their effectiveness can be investigated. It is hoped that this study will be beneficial for future studies and those who develop multimedia.

\section{$5 \quad$ Acknowledgment}

This work was supported by the Research Fund of Near East University. Project Number: SOS-2016-2-001.

\section{References}

[1] Wang, H.-Y., Liu, T.-C., Chou, C.-Y., Liang, J.-K., Chan, T.-W., \& Yang, S., (2004). A framework of three learning activity levels for enhancing the usability and feasibility of wireless learning environments. Journal of Educational Computing Research, 30(4), 331351. https://doi.org/10.2190/PWME-0H2W-GAEU-AD9P

[2] Barbara, H.,Russell, H.,Gabriel, L., James, R., Ron, V., \& Charles, W., (2005). Developing a Mobile Learning Environment to Support Virtual Education. Technological Horizons In Education, 32.

[3] Ozdamli, F., \& Yildiz, P. E., (2017). Opinions and Expectations of Parents on Integration of Mobile Technologies to Education and School Family Cooperation. International Journal of Interactive Mobile Technologies, 11 (4), 136-148. https://doi.org/10.3991/ijim. v11i4.6791

[4] Elazhary, H. (2017). Cloud-based Context-aware Mobile Intelligent Tutoring System of Technical Computer Skills. . International Journal of Interactive Mobile Technologies, 11 (4), 170-185. https://doi.org/10.3991/ijim.v11i4.6852

[5] Song, Y., \& Kong, S. C., (2017). Affordances and constraints of BYOD (Bring Your Own Device) for learning and teaching in higher education: Teachers' perspectives. Internet and Higher Education, 32, 39-46. https://doi.org/10.1016/j.iheduc.2016.08.004

[6] Yusri, I. K., Goodwin, R., \& Mooney, C., (2015). Teachers and Mobile Learning Perception: Towards a Conceptual Model of Mobile Learning for Training. Procedia Social and Behavioral Sciences, 176, 425-430. https://doi.org/10.1016/j.sbspro.2015.01. $\underline{492}$

[7] Saran, M., (2009). Exploring the use of mobile phones for supporting English language learners' vocabulary acquisition. Unpublished PhD Thesis, METU, Educational Sciences, Turkey.

[8] Alessi,S.M., \& Trollip, S.R. (2001). Multimedia for learning: Methods and development. Boston, MA: Allyn \& Bacon. 
Paper-Opinions of Teacher Candidates on the Usage of Mobile Applications in the Multimed...

[9] Moore, G. M. 1989. Three Types of Interaction. Retrieved on 10 March 2017 from: http://www.ajde.com/Contents/vol3 2.htm\#

[10] Anderson, T., (2008). Towards a Theory of Online Learning. Athabasca University: AU Press.

[11] Çuvadar, C., \& Kıyıcı, M. (2007). (ed. A. Güneş). Bilgisayar II, Ankara: Pegem A.

[12] Gülbahar, Y. (2009). e-ögrenme. Ankara: Pegem A.

[13] Oloruntoba, R. (2006). Mobile learning environments: A conceptual overview. Paper presented at Learning on the Move, Brisbane, Australia. Retrived on 21 April 2017 from: https://olt.qut.edu.au/udf/OLT2006/gen/static/papers/Oloruntoba OLT2006 paper.pdf

[14] Howell, D. J., \& Lee, T. K. (2007). M-learning: Finding a place for mobile technologies within tertiary educational settings. Proceedings Ascilite Singapore.

[15] Halis, İ. (2002). Öğretim Teknolojileri ve Materyal Geliştirme, Ankara: Nobel Publishing.

[16] Odabaş1, H. F., \& Kabakçı, I. (2007) Öğretmenlerin Mesleki Gelişimlerinde Bilgi ve Illetişim Teknolojileri. Uluslararası Öğretmen Yetiştirme Politikaları ve Sorunları Sempozyumunda sunulan bildiri, Azerbaycan: Bakü,12-14 Mayıs 2007.

[17] Mandinach, E., \& Cline, H., (1992). The impact of technological curriculum innovation on teaching and learning activities. Paper presented at the Annual Conference of the American Educational Research Association, San Francisco, California. (ERIC Document Reproduction Service No. ED 345 717).

[18] Mishra, P., \& Koehler, M.J., (2006). Technological pedagogical content knowledge: A framework for teacher knowledge. Teachers College Record, 108(6), 1017-1054. https://doi.org/10.1111/j.1467-9620.2006.00684.x

[19] Imlawi, J., Gregg, D., \& Karimi, J., (2015). Computers \& Education Student engagement in course-based social networks: The impact of instructor credibility and use of communication. Computers \& Education, 88, 84-96. https://doi.org/10.1016/j.compedu.20 15.04 .015

[20] Can, M. (2016). Use of mobile application: Means of communication between Parents and Class Teacher. World Journal on Educational Technology, 8(3), 252-257. https://doi.org/10.18844/wjet.v8i3.834

[21] Cavus, N., Uzunboylu, H., \& Ibrahim, D. (2008). Student opinion towards using an open source learning management system together with a collaborative tool. Cypriot Journal of Educational Sciences, 2 (6), 120-129.

[22] Ozdamli, F., \& Tavukcu, T. (2016). Determination of Secondary School Students' Attitudes towards Tablet PC Supported Education. Journal of Universal Computer Science, 22 (1), 4-15.

[23] Birinci, C., \& Karagözlü, D. (2016). Determination of teacher candidates' anxiety levels on using Facebook for instructional purposes. World Journal on Educational Technology: Current Issues, 8(1), 41-50. https://doi.org/10.18844/wjet.v8i1.500

[24] Tugun, V. (2016). Validity and Reliability Dissertation of the Scale Used for Determination of Perceptions and Attitudes of Teacher's Proficiency in Tablet PC-Supported Education. Cypriot Journal of Educational Sciences, 11(2), 51-57. https://doi.org/10.18844/cjes. v11i2.617

[25] Uzunboylu, H., Hursen, C., Özütürk, G., \& Demirok, M. (2015). Determination of Students' Attitudes for Mobile Integrated EFL Classrooms in Higher Education Institutions and Scale Development. Journal of Universal Computer Science, 21(10), 1283-1296. 
Paper-Opinions of Teacher Candidates on the Usage of Mobile Applications in the Multimed...

\section{$7 \quad$ Authors}

Fezile Ozdamli is member of the Association of Cyprus Education Researchers. She often works as chair for international conferences (WCETR, WCES) and is editor of the World Journal on Educational Technology. Also, she is Associate Professor Dr. in the Computer Education and Instructional Technology Department, Near East University.

Erinc Ercag is a member of the Association of Cyprus Education Researchers. Also, he is Assist Prof. Dr. at the Computer Education and Instructional Technology Department, Near East University.

Article submitted 08 September 2017. Resubmitted 29 November 2017 and 04 December 2017. Final acceptance 05 March 2018. Final version published as submitted by the authors. 